\title{
Monitoring of Utility Trenches at Mission Concepcion, San Antonio, Texas, 1988
}

Anne A. Fox

Follow this and additional works at: https://scholarworks.sfasu.edu/ita

Part of the American Material Culture Commons, Archaeological Anthropology Commons, Environmental Studies Commons, Other American Studies Commons, Other Arts and Humanities Commons, Other History of Art, Architecture, and Archaeology Commons, and the United States History Commons

Tell us how this article helped you.

This Article is brought to you for free and open access by the Center for Regional Heritage Research at SFA ScholarWorks. It has been accepted for inclusion in Index of Texas Archaeology: Open Access Gray Literature from the Lone Star State by an authorized editor of SFA ScholarWorks. For more information, please contact cdsscholarworks@sfasu.edu. 
Monitoring of Utility Trenches at Mission Concepcion, San Antonio, Texas, 1988

Creative Commons License

(c) $)(1)$ (9)

This work is licensed under a Creative Commons Attribution-NonCommercial 4.0 International License 
MONITORING OF UTILITY TRENCHES AT MISSION CONCEPCION, SAN ANTONIO, TEXÁ, I988

Anne A. Fox

Center for Archaeological Research The University of Texas at San Antonio Archaeological Survey Report, No. 180

1989 

MONITORING OF UTILITY TRENCHES AT MISSION CONCEPCION, SAN ANTONIO, TEXAS, 1988

Anne A. Fox

Center for Archaeological Research The University of Texas at San Antonio $\left({ }^{\circledR}\right.$

Archaeological Survey Report, No. 180 
A list of publications offered by the Center for Archaeological Research can be obtained by sending $\$ 1.00$ to the Center for Archaeological Research, The University of Texas at San Antonio, San Antonio, Texas 78285-0658. 


\begin{abstract}
In July 1988, personnel from the Center for Archaeological Research at The University of Texas at San Antonio conducted monitoring of the construction of hand-dug trenches for installation of an air conditioning system in the church of Mission Concepcíon. During the trenching for installation of electric lines one wall of the first convento was crossed. A small collection of artifacts taken from the backdirt of the trench is described, and the more unusual ones are illustrated.
\end{abstract}


TABLE OF CONTENTS

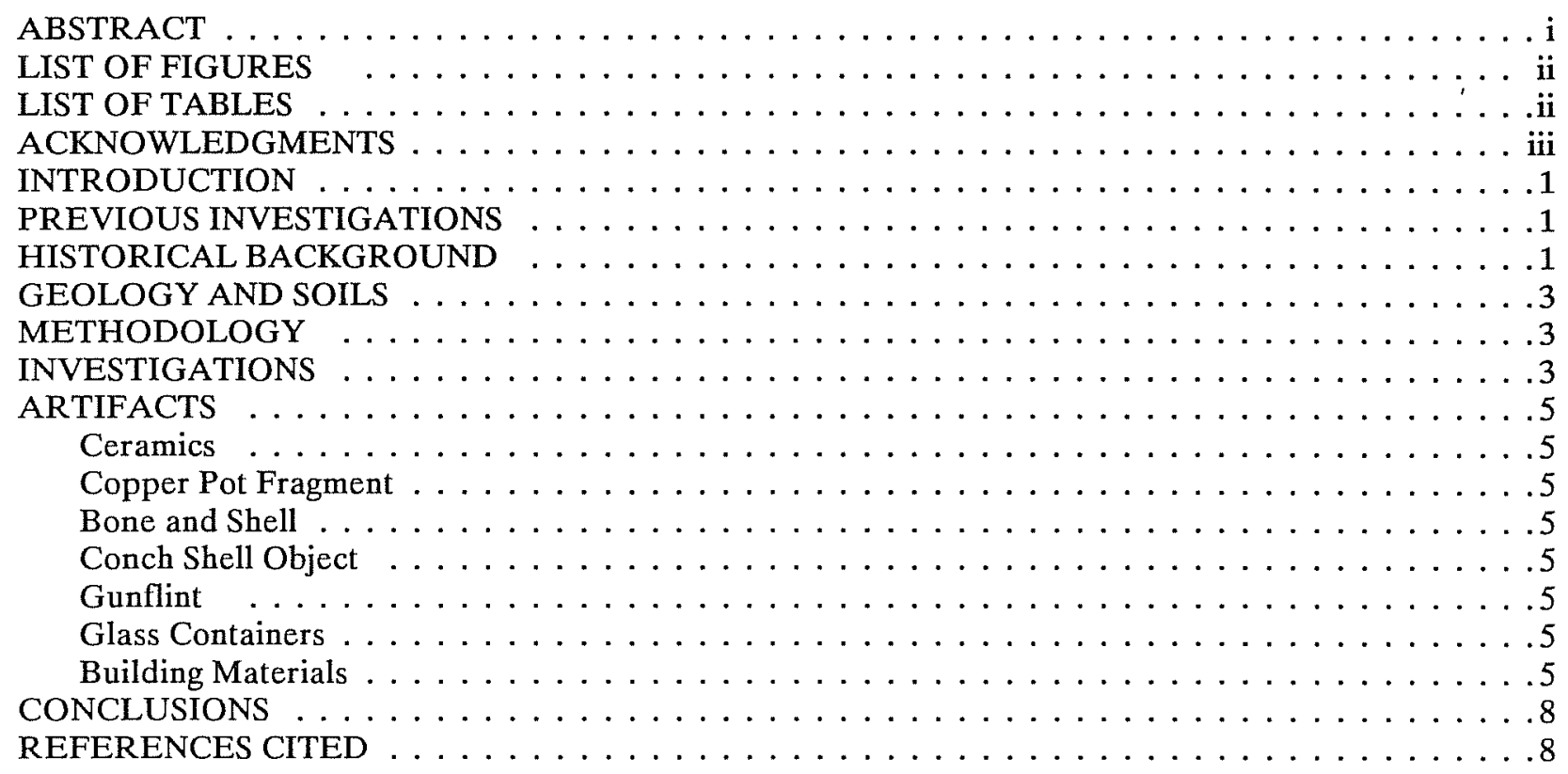

\section{LIST OF FIGURES}

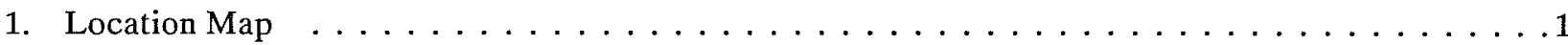

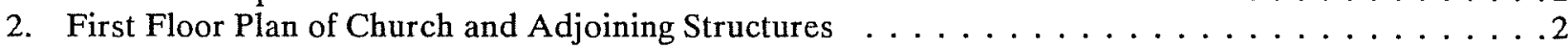

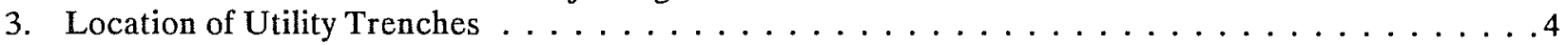

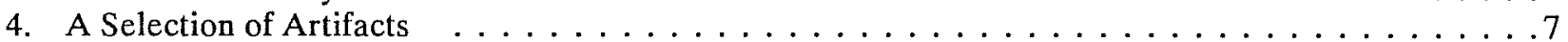

\section{LIST OF TABLES}

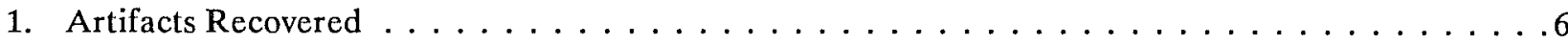




\section{ACKNOWLEDGMENTS}

The author would like to acknowledge the help and cooperation of a number of people who made the completion of this project possible. Waynne Cox and Clint McKenzie carried out most of the monitoring and artifact collection during the trenching operation, aided by Darla Cox, who volunteered her time. Carolyn Peterson of Ford Powell \& Carson Architects and Planners, Inc., coordinated the project. Our thanks also are extended to Monsignor Balthazar Janacek, in charge of the Old Spanish Missions for the Archdiocese of San Antonio, and to Robert C. Amador, superintendent, and Art Gomez, park historian, of the San Antonio Missions National Historical Park for their advice and counsel. Various supervisors and workmen of the Guido Construction Company and the Corbo Electric Company have been most cooperative throughout the project. Our thanks to Kenneth M. Brown who produced Figure 3 for this report. 



\section{INTRODUCTION}

In July 1988, archaeologists from the Center for Archaeological Research (CAR), The University of Texas at San Antonio, monitored construction related to the installation of new air conditioning units in the church of Mission Nuestra Señora de la Concepción (41 BX 12), San Antonio, Texas (Fig. 1). The work was done under contract with the Catholic Archdiocese of San Antonio and in cooperation with the National Park Service and the San Antonio Missions National Historical Park within which the mission is located. The monitoring was done in compliance with Section 106 of the National Historic Preservation Act of 1966 (as amended) and Executive Order 11593.

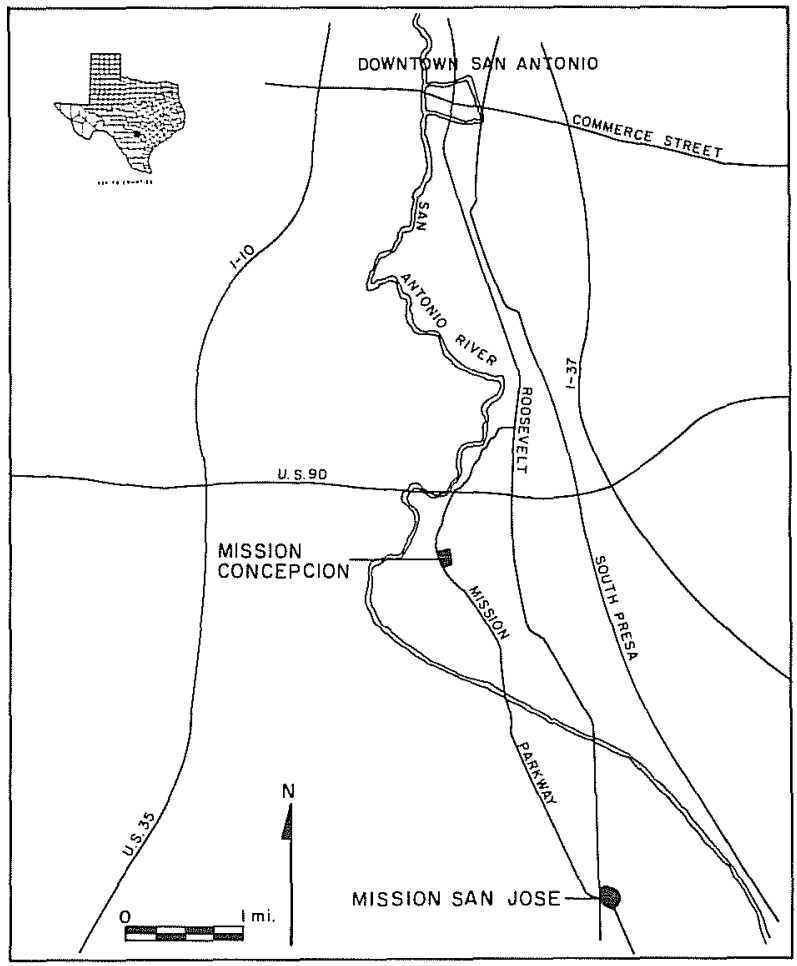

Figure 1. Location Map.

The monitoring was carried out from July 5 to July 11 during the excavation of trenches for installation of electric and condensate lines. Jack Eaton, acting director of the CAR, served as principal investigator. The author served as project director and coprincipal investigator. Approximately 34 man hours were expended by the archaeologists in monitoring, excavation, and recording.

\section{PREVIOUS INVESTIGATIONS}

In the 1930s, architect Harvey P. Smith conducted excavations around the standing mission structures for the Works Progress Administration. Smith mapped buried foundations of earlier structures, and his drawings (see Fig. 2) have been the basis for much of the archaeological work that has since been done on the site. Investigations in 1971-1972 by the Texas Historical Commission (Scurlock and Fox 1977) examined the structural condition and moisture content of the foundations of the mission church, tested to locate the west wall of the mission, and tested in the area south of the convento.

The CAR has, since 1981, conducted a series of testing operations in response to specific needs of the San Antonio Missions National Historical Park. In 1981-1982, archaeologists conducted excavations to locate the original outer walls of the mission, the granary, and the Indian quarters (Ivey and Fox n.d.). In October 1986, testing was done in the area to the south of the convento to determine the best location for a drain to carry rainwater from a low area (Fox 1988). During this testing project, foundations were mapped of a twostory convento that stood in the area until sometime in the 1760 s when the present convento took its place. The following spring, testing was done outside the west wall of the mission in preparation for the realignment of Mission Road (Labadie 1989).

\section{HISTORICAL BACKGROUND}

Mission Nuestra Señora de la Purísima Concepción was moved to the San Antonio River from east Texas in 1731 . Temporary buildings of adobe and jacal construction were built on the site. By 1756, the site was surrounded by a stone wall and the buildings included a stone granary and a two-story friary or convento (Habig 1968:129). The temporary adobe church had been demolished, and a new stone church and sacristy were in use (Ivey and Thurber 1984:3-42, 46). A new, one-story vaulted stone convento was under construction to replace the two-story structure.

The number of mission Indians began to decline, and by the time the mission was partially secularized in 1794, there were only 38 Indians still living there (Habig 1968:141-142). The mission population was supplemented by a number of Spanish families from the Villa de Bexar, who continued to cultivate the mission fields. Juan Antonio Padilla, in 1820 (Hatcher 1919:59), described the mission as being in a general state of decay, with only the church and convento still standing. The church ceased to be used for services in 1819 , the parishioners then went to the church at Mission San José. With final secularization in 1824, the administration of the church was turned over to the pastor of San Fernando Cathedral in San Antonio (Habig 1968:146). 
SCHEDULE of ROOMS (1) NAVE - gRICK PLOOR. PLASTER (2) CWANCEL- BXE GELLOW AND OVER, PLASTERED

(3) SANCTUARY- YELLOW AND BLACK (4) TRANSEPTS - FINISHED SIMILAR TO (5) SACRISTY -BRICK FLOOR. PLASTER (6) BAPTISTRY - BRICK FLOOR, WALLS AND CEILING PLASTERED. (7) TOWER ROOM- SIMILAR TO (6) walls and ceiling. OOM-DIRT FLOOR,WALLS (1)LIVING ROOM-BRICK FLOOR. WALL (11.)LIBRARY - SIMILAR TO OO (12) CLOISTER-BRICK PLLOOR. STONE (13) CELLS- DIRT PLOOR, STONE WALLS

NOTE: ROOMS S. TO HI. WERE AT ONE
TIME DECORATED WITH WALL AND CEILING MURALS WHICH ARE NOT DISTINGUISHABLE NOW.

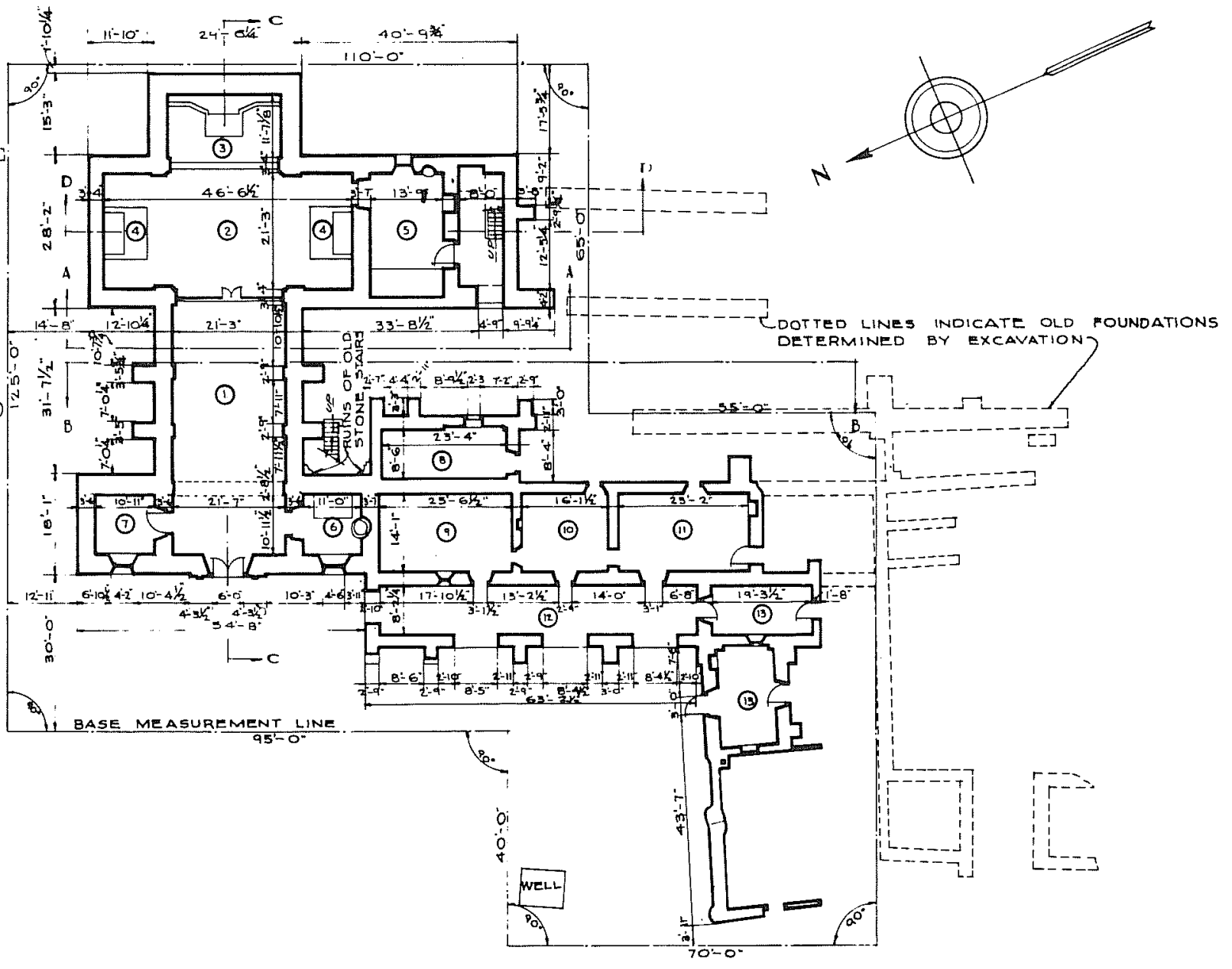

\section{FIRST $\underset{\text { SCALE: } Y_{0}=I_{-1}-O_{-}}{\text {FLAN }}$}

WELTON COOK. DEL.

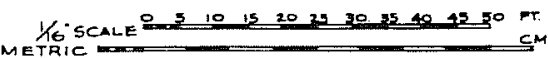
SEXAR COUNTY 
In 1824, Ramon Musquiz purchased the convento from the Mexican government (BCDR Vol. S1:480). The granary, to the east of the convento, had been acquired by Manuel Yturri y Castillo the previous year ( $B C D R$ Vol. A2:74). Yturri continued to occupy the granary until about 1838 (Ivey and Thurber 1984:3-61).

In 1859, after the mission had suffered a 20 -year period of physical decline, the Brothers of Mary obtained title to the mission and its surrounding fields. They used the mission as a training school and farm, restoring and rededicating the church in 1887 . The convento was occupied during the latter part of the 19 th century by a succession of local families (Ivey and Thurber 1984:5-8).

On November 10, 1978, Public Law 95-629, passed by the 95 th Congress, transferred the administration of Mission Concepción from the local archdiocese to the National Park Service, except for the church and sacristy which remain under the care of the Catholic church. This dual responsibility has made necessary the cooperation of the archdiocese and the National Park Service in arranging for the execution of this project.

\section{GEOLOGY AND SOILS}

The mission is located approximately one mile from the San Antonio River on an elevated spot from which it was once possible to view the entire river valley for some distance to the north and south. Soils in the general area are of the Venus-Frio-Trinity Association, grayish brown and alluvial (Taylor, Hailey, and Richmond 1966). The mission sits on a formation that is classified by the Soil Conservation Service as Hilly Gravelly Land. It consists of sediments cemented with calcium carbonates, covered by a layer of dark grayish brown clay loam (Taylor, Hailey, and Richmond 1966:17). This is an accurate description of the conditions recorded in previous excavations on the site (Scurlock and Fox 1977:33-37; Fox 1988:Fig.4). The footings of the buildings at Mission Concepción have been found to rest on the underlying caliche (consolidated calcium carbonates) formation (Fox 1988:9).

\section{METHODOLOGY}

The archaeologists monitored while the necessary trenches for the utility lines were excavated by hand; in addition, they excavated the dry well to receive condensate from the air conditioners, and consulted with the various parties involved on the best methods for carrying out the work. Field notes kept throughout the work are on file at the CAR-UTSA. Artifacts noted in the backdirt of the trench excavations were collected, washed, and cataloged, and are curated at the CAR laboratory along with other collections from the mission. Field measurements were taken in feet and inches, since the architectural drawings for the project were in that scale.

\section{INVESTIGATIONS}

At a preconstruction conference held on June 30, 1988, the archaeologists advised the architect and the contractors of the location for the dry well to receive the condensate from the air conditioning. The site chosen was expected to be free of archaeological complications.

Excavation of trenches for the condensate and electric lines (Fig. 3) was begun by workmen on July 5. The trenches were approximately two feet deep and one foot wide. The first foot was through dark grayish brown clay loam that contained fragments of animal bone and an occasional sherd of ceramic or glass. Below this was a deposit of crumbled caliche mixed with patches of the brown loam from above, which graded into solid caliche at about the level of the bottom of the trench at two feet.

The dry well was excavated by a member of the archaeological crew. A circular excavation 36 inches in diameter was dug to one foot in depth by trowel and hand pick through dark grayish brown clay loam. A few bone fragments were found near the surface, but the deposits appeared to be sterile from that point down. The pit was then dug about two additional feet into the caliche by pick and shovel. The conduit line trench was then continued until it intersected the dry well wall.

The contractor's original intention was to utilize an old electrical trench that was thought to run from the electric boxes at the south end of the property north toward the sacristy. Test trenching by the archaeologists in the vicinity of the boxes indicated that there is no such trench. Therefore, the electric line would have to be run in a new trench north to south across the area.

Monitored excavation on July 6 was limited to finishing the trenches to the north of the restroom sidewalk. Pipes were laid, and trenches were backfilled in this area.

On July 7, monitored trenching began south of the sidewalk. In this area, patches of caliche were closer to the surface, sometimes as close as four inches below the grass roots. In the area of the north wall foundation of the two-story convento, the wall was found to extend across the electrical trench, the top being six to eight inches below the surface. There was, however, no sign of a similar foundation for the south wall. 


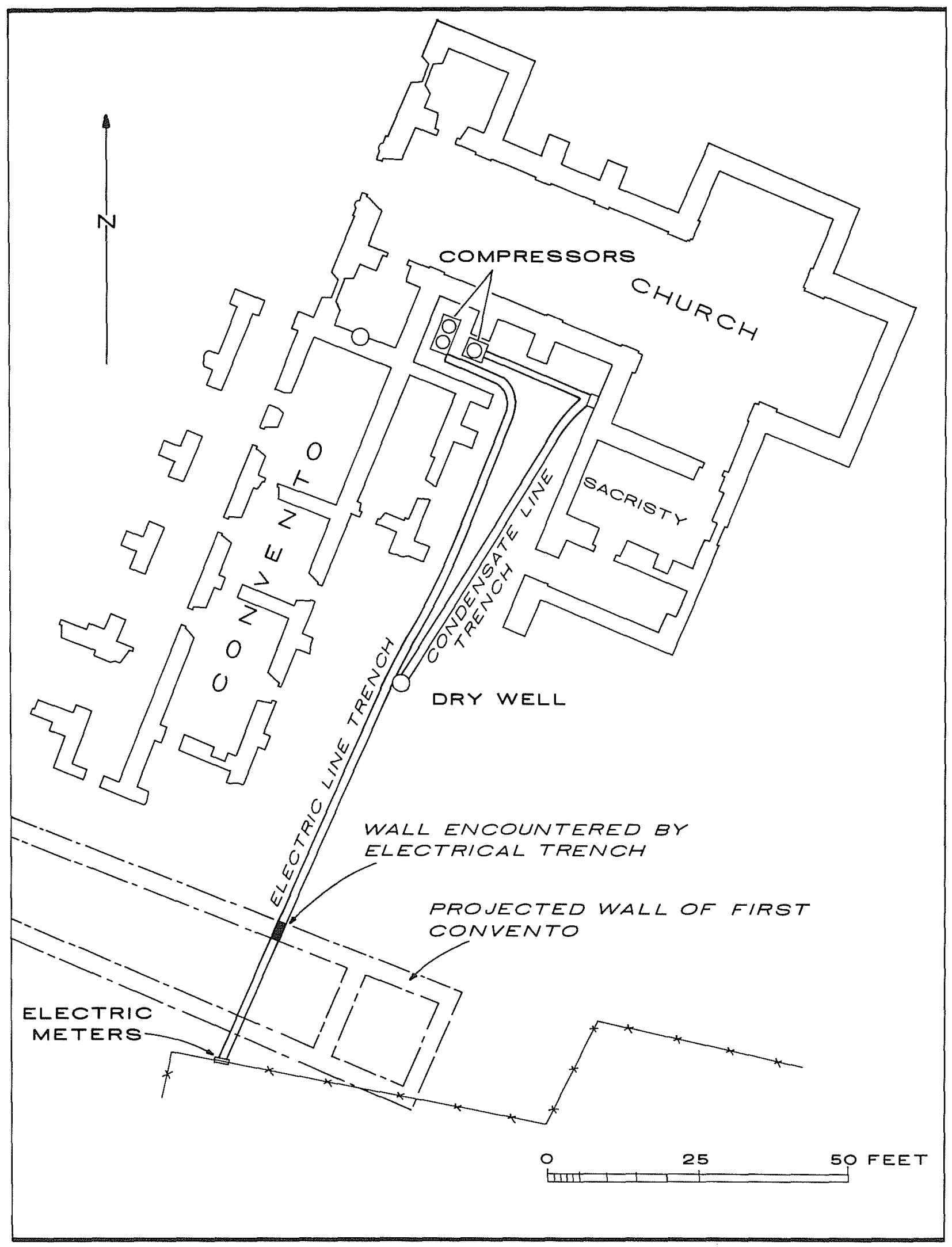

Figure 3. Location of Utility Trenches. 
The archaeologists noted numerous Spanish colonial and English ceramic sherds and other artifacts in the electrical trench from the location of the convento north wall to the chain link fence at the south edge of the property. These were recovered for study.

During a conference on site between the archaeologists, the architect, the contractor, and representatives of the National Park Service, several possible ways to carry the pipe across the wall footing was discussed. The consensus was that the least destructive method would be to cut a notch in the top of the footing just wide and deep enough to receive the pipe to contain the electrical lines. Any alternative routes appeared to encounter wall footings or other pipes, and tunneling beneath the footing would mean cutting through the supporting basal caliche and probably weakening what is left of the original foundation. A telephone consultation with a representative of the Texas Historical Commission resulted in permission to cut the trench, and on July 11, the archaeologists monitored the excavation. The laying of the pipe and the backfilling of trenches could then be completed.

\section{ARTIFACTS}

Since the artifact collection is small and provenience is not precise, discussion and illustration of individual artifacts are limited to those that are unusual or remarkable from the point of view of the site as a whole. For more detailed description and discussion of the various ceramic types, see reports by Davis and Corbin (1967:14-30), Fox, Bass, and Hester (1976:54-67), and Ivey and Fox (1981:30-35). For discussion of similar Spanish colonial artifacts found on other local sites, see reports by Schuetz (1969) and Ivey (1983). See Table 1 for the types and amount of each artifact type collected.

\section{Ceramics}

The varieties of ceramics found correspond well with those recovered from the same area in 1987 (Fox 1988:11-14) and in 1981 (Ivey and Fox n.d.). The number of sherds representing vessels from the Spanish colonial period is about equal to the number from the first part of the 19th century, when the Musquiz and Yturri families occupied the nearby buildings.

\section{Copper Pot Fragment}

A piece of sheet copper $1 \mathrm{~mm}$ in thickness is wrapped around a section of copper rod $3.5 \mathrm{~mm}$ in diameter. Large copper cauldrons were brought to the frontier by the Spanish supply trains for use in the mission kitchens. The author has observed that these utensils were sometimes reinforced by rolling the rim over a heavy wire or rod.

\section{Bone and Shell}

It is customary to find fragments of bone and mussel shell in the middens that accumulated outside the mission gates. Evidently some of the same sort of trash was thrown into this area, perhaps after the missionaries were no longer present to urge cleanliness. The majority of the bone was found in the area between the sacristy and the convento, at the north end of the utility trenches.

\section{Conch Shell Object}

A circular-shaped shell ornament with two drilled holes near the center (Fig. 4,a) is similar to conch shell pendants found on the Texas coast and described in a report by Janota (1980:41-43); but this one is slightly smaller. This object measures $2.8 \mathrm{~cm}$ at its maximum dimension. Both holes appear to have been biconically drilled, and there is considerable polish on the convex surface of the object. Since coastal Indians are known to have entered this mission (Habig 1968:132, 133, 136; Campbell and Campbell 1985), it should not be surprising to find such a typically coastal object.

\section{Gunflint}

A battered musket flint (Sam Nesmith, personal communication) of dark brown chert shows signs of much use. Its maximum width is $3 \mathrm{~cm}$, and it has a maximum thickness of $8 \mathrm{~mm}$ (Fig. 4,b).

\section{Glass Containers}

The time period represented by the glass items reflects the 18th (Fig. 4,c) and early 19th centuries, with the addition of contemporary soft drink bottle fragments. A few contemporary artifacts were found near the surface in this area in 1987 (Fox 1988:15, 17).

\section{Building Materials}

Fragments of modern window glass and brick found during the trenching probably represent a turnof-the-century frame house that was built nearby according to early photographs in the collections of the San Antonio Missions National Historical Park. In addition, however, objects were found relating to colonial construction, such as a fragment of low-fired handmade brick. 
TABLE 1. ARTIFACTS RECOVERED

Animal Bone

Ceramics

Banded slip ware

Bisque painted hat

Blue and green spattered ware

Blue-on-white majolica

Blue shell edged ware

Galera ware

Goliad ware

Green-glazed sandy paste ware

Green-on-cream majolica

Guanajuato majolica

Hand-painted ware

Huejotzingo majolica

Lusterware

Oriental porcelain

San Elizario majolica

Stoneware

Transferware

Undecorated majolica

Undecorated whiteware

Yellow-glazed sandy paste ware

Glass

Brown beer bottle

Clear glass tumbler, pontil

Contemporary soda bottle

Hand-blown bottle

Mold-made bottle

Olive wine bottle

Window glass

Metal

Barrel strapping

Copper/brass plate

Copper pot

Cut nail

Musket flint

Spanish hinge (gozne)

Miscellaneous

Colonial brick

Contemporary brick

Shell

Conch shell object

Mussel shell
161 fragments

2 sherds

8 sherds

6 sherds

1 sherd

6 sherds

7 sherds

10 sherds

7 sherds

4 sherds

1 sherd

2 sherds

2 sherds

1 sherd

1 sherd

2 sherds

1 sherd

1 sherd

6 sherds

14 sherds

1 sherd

1 fragment

1 fragment

3 fragments

2 fragments

2 fragments

5 fragments

9 fragments

2 fragments

1

1 fragment

1

1

1

1 fragment

1 fragment

1

1 fragment 


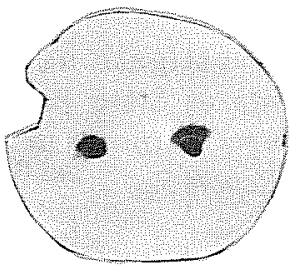

a

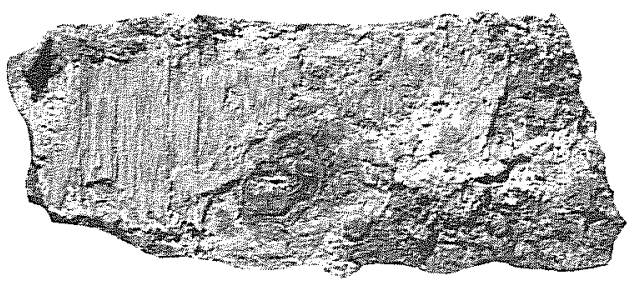

d

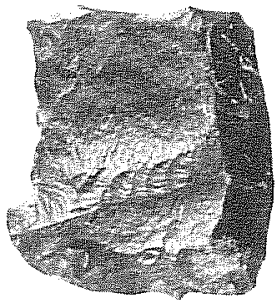

b
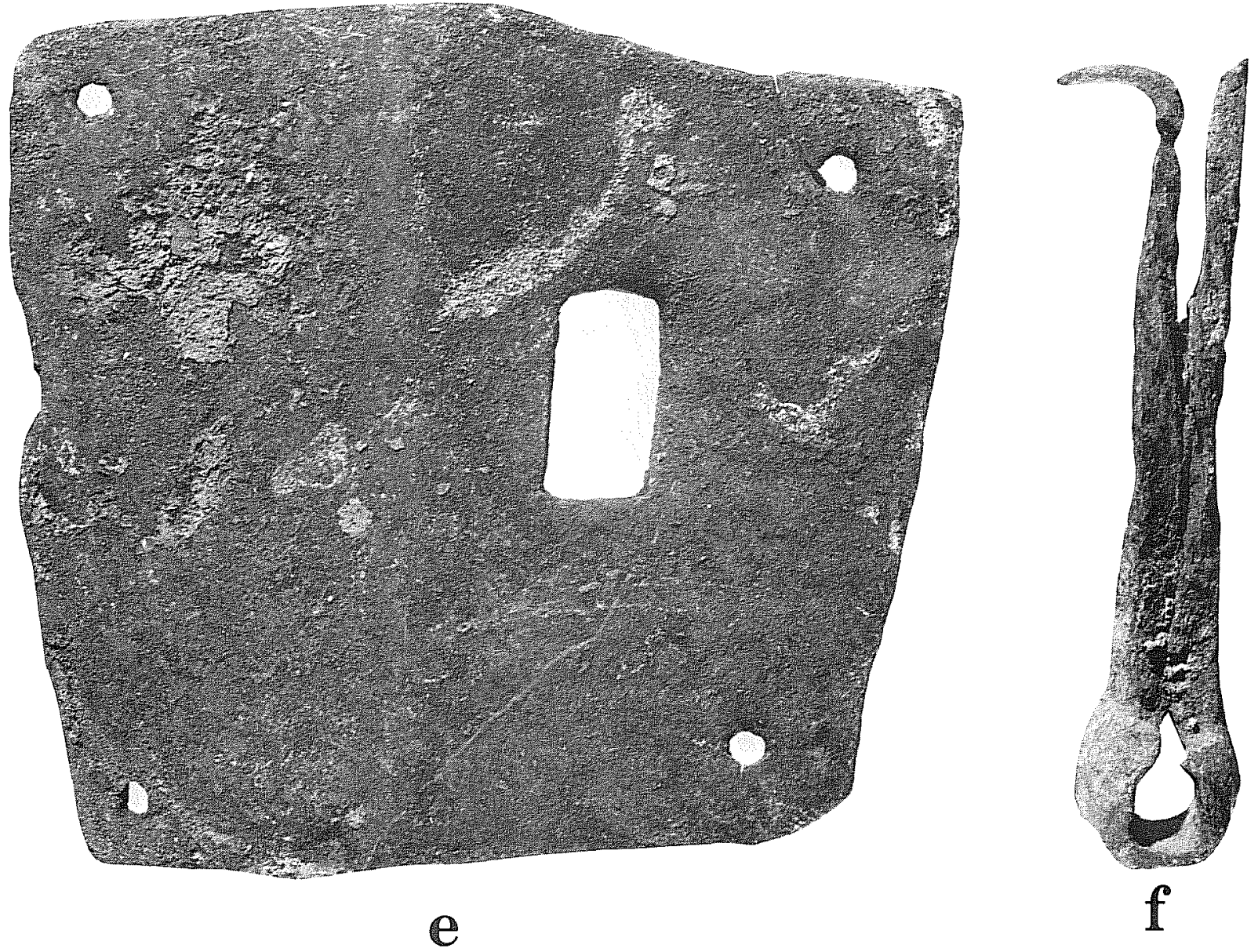

Figure 4. A Selection of Artifacts. a, conch shell object; b, gunflint; c, glass tumbler with pontil mark; d, iron barrel hoop fragment; e, copper plate; f, snipe hinge. 
Two fragments of an iron barrel hoop (Fig. 4,d) still retain fragments of the wood from the barrel cemented by rust to their inside curve. Numerous supplies were shipped in barrels in early Texas, especially during the first half of the 19th century.

A heavy copper plate (Fig. 4,e) is apparently part of a door latch mechanism. A crease shows where it was originally bent around the edge of a heavy door, and a rectangular hole has been chiseled out to receive a door latch. The object was crudely cut and shaped of 2.5-mm-thick sheet metal.

An unusual Spanish object found is a snipe hinge or gozne (Fig. 4,f) with long pointed ends meant to be driven through a door or door frame at a $45^{\circ}$ angle and bent over on the opposite side (Simmons and Turley 1980:135-137). What makes this one interesting is that instead of being one of an identical, interlocking pair, it is shaped to receive a pintle.

\section{CONCLUSIONS}

Monitoring of this project contributed to its overall successful conclusion without seriously damaging cultural resources in the area. The advice of the archaeologists on the location of the trenches and the dry well helped avoid most archaeological complications. The unavoidable problem of the convento wall appears to have been worked out to the satisfaction of all parties involved. We recommend that the same process be followed in the event of future construction projects at the missions.

\section{REFERENCES CITED}

Bexar County, Texas

Bexar County Deed Records (BCDR)

Originals and microfilm located in the basement of the Bexar County Courthouse, San Antonio, Texas.

Campbell, T. N. and T. J. Campbell

1985 Indian Groups Associated With Spanish Missions of the San Antonio Missions National Historical Park. Center for Archaeological Research, The University of Texas at San Antonio, Special Report 16.

Castañeda, C. E.

1936 The Mission Era: The Founding of Texas, 1519-1693. Our Catholic Heritage in Texas, 1519-1936. Vol. I. Von Boeckmann-Jones Company, Austin.
Davis, E. M. and J. E. Corbin

1967 Archeological Investigations at Washington-on-the-Brazos State Park in 1966. State Building Commission Archeological Program, Report 5.

Fox, A. A.

1988 Archaeological Excavations at Mission Concepción, Fall of 1986. Center for Archaeological Research, The University of Texas at San Antonio, Archaeological Survey Report 172.

Fox, A. A., F. A. Bass, Jr., and T. R. Hester

1976 The Archaeology and History of Alamo Plaza. Center for Archaeological Research, The University of Texas at San Antonio, Archaeological Survey Report 16.

Furey, F. J.

1974 Archdiocese of San Antonio, 1874-1974. Archdiocese of San Antonio, Texas.

Habig, Fr. M. A.

1968 The Alamo Chain of Missions, A History of San Antonio's Five Old Missions. Franciscan Herald Press, Chicago.

Hatcher, M. A., translator

1919 Texas in 1820 , by Juan Antonio Padilla. Southwestern Historical Quarterly 23:47-68.

Ivey, J. E.

1983 Archaeological Testing at Rancho de las Cabras, Wilson County, Texas, Second Season. Center for Archaeological Research, The University of Texas at San Antonio, Archaeological Survey Report 121.

Ivey, J. E. and A. A. Fox

1981 Archaeological Survey and Testing at Rancho de las Cabras, Wilson County, Texas. Center for Archaeological Research, The University of Texas at San Antonio, Archaeological Survey Report 104.

n.d. Archaeological Investigations at Mission Concepción and Mission Parkway. Center for Archaeological Research, The University of Texas at San Antonio, Archaeological Survey Report 114. Manuscript on file. 
Ivey, J. E. and M. B. Thurber

1984 The Missions of San Antonio, A Historic Structures Report and Administrative History. Part I: The Spanish Colonial Missions, edited by Tom Ireland. National Park Service, Southwest Cultural Resources Center, Santa Fe, New Mexico. Draft report on file at the Center for Archaeological Research, The University of Texas at San Antonio.

Janota, B.

1980 A Preliminary Study of the Shell Ornaments of the Texas Coast Between Galveston Bay and the Nueces River. In Papers on the Archaeology of the Texas Coast, edited by L. Highley and T. R. Hester:29-50. Center for Archaeological Research, The University of Texas at San Antonio, Special Report 11.

Labadie, J. H.

1989 Archaeological and Historical Investigations for the Mission Road Realignment Project, San Antonio, Texas. Center for Archaeological Research, The University of Texas at San Antonio, Archaeological Survey Report 173.

Schuetz, M. K.

1969 The History and Archeology of Mission San Juan Capistrano, San Antonio, Texas. Vol. II. State Building Commission Archeological Program, Report 11.

Scurlock, D. and D. E. Fox

1977 An Archeological Investigation of Mission Concepción, San Antonio, Texas. Office of the State Archeologist, Report 28.

Simmons, M. and F. Turley

1980 Southwestern Colonial Ironwork, The Spanish Blacksmithing Tradition From Texas to Califomia. Museum of New Mexico Press, Santa Fe.

Taylor, F. B., R. B. Hailey, and D. L. Richmond 1966 Soil Survey, Bexar County, Texas. U.S. Department of Agriculture, Soil Conservation Service in cooperation with Texas Agricultural Experiment Station, Series 1962(12). 
